\title{
The Role of Audit Committee of GCG in Increasing Company Value through ROA
}

\author{
Ana Kadarningsih ${ }^{1}$ \\ Irene Rini Demi Pangestuti ${ }^{2}$ \\ Sugeng Wahyudi ${ }^{2}$ \\ Julia Safitri ${ }^{3}$ \\ ${ }^{1}$ Diponegoro University, \\ Doctoral Student of Economics and Business Faculty; \\ Lecturer of Dian Nuswantoro University, Indonesia \\ ${ }^{2}$ Diponegoro University, \\ Economics and Business Faculty, Indonesia \\ ${ }^{3}$ Diponegoro University, \\ Economics and Business Faculty; \\ Lecturer of STIE IPWIJA, Indonesia
}

DOI: https://doi.org/10.36941/ajis-2020-0057

\section{Abstract}

This study determines the Good Corporate Governances (GCG) influence in increasing company value through Return on Assets (ROA). Good Corporate Governance factors used in this research are independent commissioner (IC) and audit committee (AC). Company Value factors used in this research is PBV (Price to Book Value). Sample of this research contains 23 conventional commercial banks registered on IDX (Indonesia Stock Exchange) in the period of 2014-2018. The method of data analysis uses multiple linear regression. The results show that the fastest variable to increase company value through ROA as a mediating variable is the audit committee. Independent commissioner does not influence on financial performance (ROA) and company value. Another variable that rapidly increases company value is the direct influence of intellectual capital on company value.

Keywords: GCG, ROA, PBV, Conventional Bank, Intellectual Capital

\section{Introduction}

Bank has a function as an intermediary financial between the capital owners and needs capital to expedite the flow of payments. The bank's business activities are started from the people's trust. Therefore, bank managers in their operations are required to regulate the balance between adequate liquidity with the fairness of profitability and meet the suitability of adequate types of capital investment. Bank deserves to be trusted if the bank prioritizes to increase company value in each period (Kartikasari, 2017). The company value illustrates profits that earned by company. To find out the company's profits, investors can calculate the rate of return on assets. High company value can 
increase financial performance.

Financial performance is influenced by several factors such as intellectual capital (IC), profitability, GCG, and company value. IC is intangible capital and is connected to technology and science in which there is a hidden company value. Intellectual capital can be counted using VAIC (Value Added Intellectual Capital). VAIC ${ }^{\mathrm{TM}}$ uses financial reports to find the added value of three indicators, namely human capital (HC), structural capital (SC), and employed capital (CA). Value added is a dimension in creating company value. If the VAIC ${ }^{\mathrm{TM}}$ is higher, it indicates that company is increasingly shrewd in maximizing its capital (Ulum, 2009). Arini (2018) stated that GCG is a regulatory system which manages the relationships among company management, loan customers, shareholders, workers, the government and other inside and outside stakeholders, and their rights and obligations. GCG aims to produce value-added for shareholders or related parties. In GCG, there are several mechanisms used including independent commissioners and audit committees (Arini, 2018).

Ulum (2009) stated that there is an influence between financial performance (ROA) and VAIC, i.e. if the value of VAIC ${ }^{\mathrm{TM}}$ is higher, the company is getting better at maximizing its capital. VAIC has a positively relationship with on financial performance. If increasing VAIC will result in increased ROA, then decreasing VAIC will result in decreased ROA (Ulum, 20o8). This was not seen in 9 banks namely BBNI, BBRI, BDMN, BINA, BNGA, BNII, BSIM, BVIC, MCOR which showed that VAIC had a negatively impact on financial performance. This phenomenon is in line with Daud and Amri (2008); Kuryanto and Syafruddin (2008) stating that VAIC has a negatively impact on financial performance. Meanwhile, Arini (2018) and Kartikasari (2017) found that VAIC affects financial performance positively. If the VAIC is increased, it will produce an increase in ROA as well follow all submission guidelines when formatting an article or it will be returned for reformatting.

Financial performance is positively influenced by the audit committee (Kartikasari, 2017). The existence of committees is more effective in increasing company profitability. However, some audit committees cannot guarantee function of supervision, quality of financial annual reports, and control of the company's management running well.

\section{Literature Review}

\subsection{Value Added Intellectual Capital - VAIC ${ }^{\mathrm{Tm}}$}

$\mathrm{VAIC}^{\mathrm{TM}}$ is a method designed to efficiently present value creation information of intangible and company tangible assets. Junaedi (2017) defined VA (Value Added) as a measure to assess business success and the company capability to objectively create value. The main components of VAIC ${ }^{\mathrm{Tm}}$ include Structural Capital Value Added (STVA), Value Added Human Capital (VAHU), and ValueAdded Capital Employed (VACA) (Pratiwi, 2017). VACA is a ratio among value-added (VA) and physical capital (CA). VAHU assumes how far the value-added (VA) can be achieved with the capital used for the workforce. STVA assess the minimum sum of capital (SC) used to obtain added value as proof of the success of capital structure in value procurement. SC is a small contribution in value procurement because it is not as an independent measure like HC. SC is VA minus HC (Pratiwi, 2017).

\subsection{Good Corporate Governance - GCG}

GCG can be calculated with an independent commissioner (IC) and audit committee (AC). The independent commissioners are board commissioners which are parts from the company's external who work independently in conducting oversight of board commissioners' performance (Arini, 2018). Furthermore, she states that the higher of independent commissioners' amount in the overall board of commissioners, the greater the level of conservatism used. Strong board commissioners have high proportion of IC, thus board commissioner can encourage management to conduct conservative accounting to produce quality financial statement information. Variable of IC in this study was calculated by referring to the research of Arini (2018), namely the total independent commissioners 
divided by total board of commissioners. Meanwhile, audit committee is measured by members of an audit committee owned by a firm. The audit committee is composed, appointed, and dismissed by the board of commissioners for helping examine the implementation of the directors' functions. The audit committee membership consists of at least three persons, one of who are an independent commissioner and concurrently the audit committee's chair, while the other two members are independent external parties, and among them must-have capabilities in financial accounting. The audit committee is responsible for providing independent professional opinions to the commissioners and determining matters that must be considered by the board of commissioners (Arini, 2018). The audit committee is calculated from the number of audit committees divided by the number of commissioners. (Haryani and Wiratmaja, 2014).

\subsection{Company Value}

The bank's business activities are started from public trust. As a trust enterprise, banks in carrying out their operations use a lot of capital from the public or capital owners. Therefore, bank managers in their operations are needed to maintain liquidity balance with reasonable profitability and reasonable capital adequacy by following the type of capital investment. These operations aim to help and facilitate raising funds and issuing funds in the form of current assets such as loans and securities. As proof, a bank deserves to be trusted if the bank prioritizes the smoothness of the parties needing funds to complete their obligations. In reality, many banks experience high bad credit problems. This problem can occur because banks are competing to attract customers by distributing easy loans so that banks do not use the precautionary principle. This condition influences the company value (Kartikasari, 2017). Company value in this study is used to measure PBV (Price to Book Value) proxy. Arini (2018) stated that the company value is determined by the market price for each share compared by the book value per share.

\subsection{Hypothesis Development}

Hadiwijaya and Rochman (2013) supported that the company is optimistic to get a large profit by using Intellectual Capital efficiently and effectively that reflects financial performance. The reason is the fund placement for intellectual capital can accelerate the company quality, thereby increasing the enterprise's profitability. Having a high VAIC makes a future investment for the firm. By following stakeholder theory which explain that value-added is a valid measurement tool compared to accounting earnings, so the role of Intellectual Capital is very important for enterprises to improve company performance (Maryanto, 2017). Therefore, it can be concluded that hypothesis 1 is as follows:

Hypothesis 1: VAIC ${ }^{\mathrm{TM}}$ significantly and positively affects financial performance (ROA)

The findings of previous studies on the relationship among Independent Commissioner and Return on Assets (ROA) show the independent commissioner significantly and positively affects ROA. The high proportion of independent directors makes more share ownership and makes investors trust the company with more shares making financial performance go up (Kartikasari, 2017). Furthermore, hypothesis 2 can be formulated as follows:

Hypothesis 2: Independent Commissioner significantly and positively affects ROA.

The previous studies about the impact of AC on ROA show that AC has a positive significant relationship with the company's financial performance. It is in line with Kartikasari (2017) explaining that AC has a significant effect on profitability and ROA. Therefore, hypothesis 3 can be determined as follows:

Hypothesis 3: The Audit Committee significantly and positively affects ROA of banks.

The results of previous study on the effect of VAIC ${ }^{\mathrm{TM}}$ on Company Value (PBV) show that VAIC ${ }^{\mathrm{TM}}$ has a significant impact on firm value. This is in line with Arini (2018) which stated that IC has a significant positive effect on firm value. However, it is different from Yuniasih et al. (2010) which said that IC had no influence on firm value due to investors who had not considered intellectual capital in 
assessing company performance. Based on previous research, hypothesis 4 can be determined as follows:

Hypothesis 4: VAIC ${ }^{\mathrm{TM}}$ significantly and positively affects Company Value (PBV)

The previous studies found that PBV is positively and significantly influenced by independent commissioners. These results are in line with research from Maryanto (2017) which explained that the more members of IC the enterprise will improve performance so that company value increases. Independent commissioners have been able to enhance the company value because investors believe the investor will often invest in the firm's shares. The existence of the commissioner board is highly considered by investors since it can improve company value. Furthermore, hypothesis 5 can be concluded as follows:

Hypothesis 5: IC shows a significant and positive correlation with PBV.

The results of previous studies on the impact of AC on Company Value shows that there is a significant and positive relationship among the audit committee on the company's value because the audit committee has been able to enhance the enterprise value and the audit committee's duties are maximized according to the existing regulations. Mukhtaruddin et al. (2014) said that audit committee significantly and positively affects company value. The more optimal of audit committee's role in running the functions of supervision and management control, the better the company value and good management accountability. This finally makes the trust of investors higher so that it increases the company value. Therefore, hypothesis 6 can be formulated as follows:

Hypothesis 6: AC significantly and positively affects PBV.

The findings of previous studies indicate that company value is influenced by financial performance. If financial performance determined by ROA increases company value will also grow. Arini (2018) stated that ROA will increase profits earned by the company that carries out its operational activities. The profits obtained by the company are distributed to investors as an attraction and value-added for the company. It is also in line with Yuniasih (2008), Imron (2013) and Nisasmara et.al (2016) which described that financial performance has a positive and significant influence on PBV. Thus, hypothesis 7 can be formulated as follows:

Hypothesis 7: ROA significantly and positively affects PBV

\section{Research Method}

The independent variables of this research are $\mathrm{VAIC}^{\mathrm{TM}}$, IC and $\mathrm{AC}$, while then the dependent variable is PBV. Financial performance (ROA) serves as a mediating variable between VAIC ${ }^{\mathrm{T}}$, IC, and AC on Company Value. The population of this study consists of conventional commercial banks registered on IDX in the period of 2014-2018. Purposive sampling technique is used to determine certain criteria from the sample. The sample of this study includes 23 banks with the following criteria:

1. Bank enterprises listed on IDX in the period of 2014-2018.

2. Bank enterprises that provide complete financial statements to measure ROA (Return on Assets) in the period of 2014-2018.

Secondary data collection uses the documentation method. The documentation method is technique of data collection by using journals, books, literature studies from various literatures, as well as other sources related to research. Data related to this research is financial reports of financial sector companies registered on the Stock Exchange in the period of 2014-2018 obtained from the IDX website (Indonesian Stock Exchange).

\section{Result and Discussion}

\subsection{Descriptive Statistics}

Descriptive statistics is a statistical tool that aims to provide a general description of the data and objects of research without analyzing the function of describing or providing a general description of 
the object under study, as well as without conducting analysis and drawing general conclusions. General description of data consists of minimum, maximum, average, and standard deviation. Descriptive statistics can be explained in Table 4.1 below:

Table 4.1: Descriptive Statistics

\begin{tabular}{lccccc}
\hline & $\mathrm{N}$ & Min. & Max. & Mean & Std. Dev. \\
\hline VAIC & 115 & 2.35 & 39.50 & 8.3834 & 5.51240 \\
IC & 115 & .20 & .80 & .4940 & .14746 \\
AC & 115 & .38 & 1.67 & .9142 & .29567 \\
ROA & 115 & .13 & 11.60 & 1.4531 & 1.58948 \\
PBV & 115 & .28 & 4.72 & 1.5967 & 1.03370 \\
Valid N (listwise) & 115 & & & & \\
\hline
\end{tabular}

4.2 The Influence of Intellectual Capital (VAIC), Independent Commissioners (IC), and Audit Committees (AC) on ROA

Regression analysis used multiple linear to find the impact of VAIC, IC and AC on ROA and the influence of VAIC, IC, and AC on PBV and the impact of ROA on PBV.

In the first model, this study analyzed the influence of VAIC, Independent Commissioner and Audit Committee on ROA in the period 2014 - 2018 at conventional commercial banks on the IDX where the regression equation results can be seen in Table 4.2 below:

Table 4.2: Coeff. $^{\mathrm{a}}$

\begin{tabular}{|c|c|c|c|c|c|c|c|}
\hline \multirow{2}{*}{ Model } & \multicolumn{2}{|c|}{ Unstand. Coeff } & \multirow{2}{*}{$\begin{array}{c}\text { Stand. Coeff. } \\
\text { Beta } \\
\end{array}$} & \multirow{2}{*}{$\mathrm{t}$} & \multirow{2}{*}{ Sig. } & \multicolumn{2}{|c|}{ Collinearity Statistics } \\
\hline & $\mathrm{B}$ & Std. Err & & & & Tolerance & VIF \\
\hline (Constant) & 2.419 & .314 & & $7 \cdot 712$ & .000 & & \\
\hline VAIC & -.033 & .016 & -.173 & -2.084 & .040 & .997 & 1.003 \\
\hline${ }^{1}$ IC & .704 & .461 & .128 & 1.526 & .130 & .964 & 1.037 \\
\hline $\mathrm{AC}$ & -1.408 & .230 & -.516 & -6.125 & .000 & .964 & 1.037 \\
\hline
\end{tabular}

a. Dependent Variable: ROA

The results of calculations using the SPSS program show a probability value of $0.040<0.05$ (the significance level is $5 \%$ ). This means that there was a significant impact among VAIC on Financial Performance partially. This significant effect shows that VAIC level influences financial performance improvement. This result is in line with Maryanto (2017); Ulum (2008); Arini (2018), and Kartikasari (2017) which stated that intellectual capital determined by VAIC positively and significantly affects ROA.

The calculations using the SPSS program show that the probability value is $0.130>0.05$ (the significance level is $5 \%$ ). Thus, there is no significant effect between IC on ROA partially. This means that increasing the sum of independent directors cannot improve financial performance. It is in line with Rimardhani et al. (2016), Ferial et al. (2014) and Buallay et al. (2017) stating that IC has no impact on ROA.

Table 4.2 shows that AC positively and significantly affects ROA partially with a probability value of $0.000<0.05$ (the significance level is $5 \%$ ). This means that an increase in financial performance is influenced by an increase in the number of AC. Conversely, if the number of KA decreases then financial performance also decreases. It is in line with Kartikasari (2017) and Pratiwi (2017) which explained that audit committees have significant and positive effect on financial performance. 
4.3 The Impact of Intellectual Capital, Independent Commissioners, Audit Committees, and ROA on $P B V$

In the second model, this research analyzed the impact of VAIC, Independent Commissioner, AC and ROA on PBV in the period of 2014 - 2018 at conventional commercial banks listed on the IDX. The findings of the regression equation can be seen in Table 4.3 below:

Table 4.3: Coeff. $^{\mathrm{a}}$

\begin{tabular}{|c|c|c|c|c|c|c|c|}
\hline \multirow{2}{*}{ Model } & \multicolumn{2}{|c|}{ Unstand. Coeff. } & \multirow{2}{*}{$\frac{\text { Stand. Coeff. }}{\text { Beta }}$} & \multirow{2}{*}{$\mathrm{t}$} & \multirow{2}{*}{ Sig. } & \multicolumn{2}{|c|}{ Collinearity Statistics } \\
\hline & $\mathrm{B}$ & Std. Err & & & & Tolerance & VIF \\
\hline (Constant) & -.948 & .462 & & -2.052 & .043 & & \\
\hline VAIC & .079 & .019 & .315 & 4.100 & .000 & .956 & 1.046 \\
\hline IC & -.233 & .547 & -.033 & -.426 & .671 & .943 & 1.061 \\
\hline $\mathrm{AC}$ & .988 & .315 & .280 & 3.138 & .002 & .707 & 1.415 \\
\hline ROA & .949 & .116 & .735 & 8.207 & .000 & .704 & 1.421 \\
\hline
\end{tabular}

a. Dependent Variable: Company Value

Table 4.3 shows that the probability value is $0.000<0.05$ (the significance level is $5 \%$ ). This implies that there is significant and partial effect of VAIC on Company Value. It indicates that the level of VAIC influences the increase of company value. It is in line with Junaedi (2017) and Pratiwi (2017) stating that intellectual capital can increase company value.

The findings of calculations using the SPSS program show that the probability value of $0.671>$ 0.05 (a significance level of 0.05 or $5 \%$ ). It implies that there is no significant impact of the Independent Commissioners on Company Value partially. The absence of significant influence shows the rating of the Independent Commissioner does not influence the increasing of PBV. It is in line with Arini (2018) and Khosa (2017) stating that IC has no significant impact on PBV.

The results of calculations using the SPSS program show that the probability value of $0.002<$ 0.05 (the significance level is $5 \%$ or 0.05 ). This explains that there is significant effect of AC on PBV partially. It indicates that the number of audit committees can affect the increase of company value. It is in line with Mukhtaruddin et al. (2014) and Khan et al. (2017) stating that audit committee shows significant and positive correlation with company value.

In addition, Table 4.3 shows that there is a meaningful correlation between financial performance and the company value partially, with a probability value of $0.000<0.05$ (the significance level is $5 \%$ or 0.05 ). This positive and significant effect shows that better financial performance can influence the growth of PBV. Conversely, worse ROA has an impact on the decline in PBV. It is in line with Arini (2018), Yuniasih (2008) and Imron (2013) which said that financial performance significantly and positively affects company value.

This research used Sobel Test to know the significance for mediating variable. ROA as a mediating variable can mediate correlation between company value and audit committee. The result of the Sobel Test shows that Return On Assets as a mediating variable shows significant effect of Audit Committees (AC) on Company Value (PBV). It can be seen in Figure 4.1 below: 


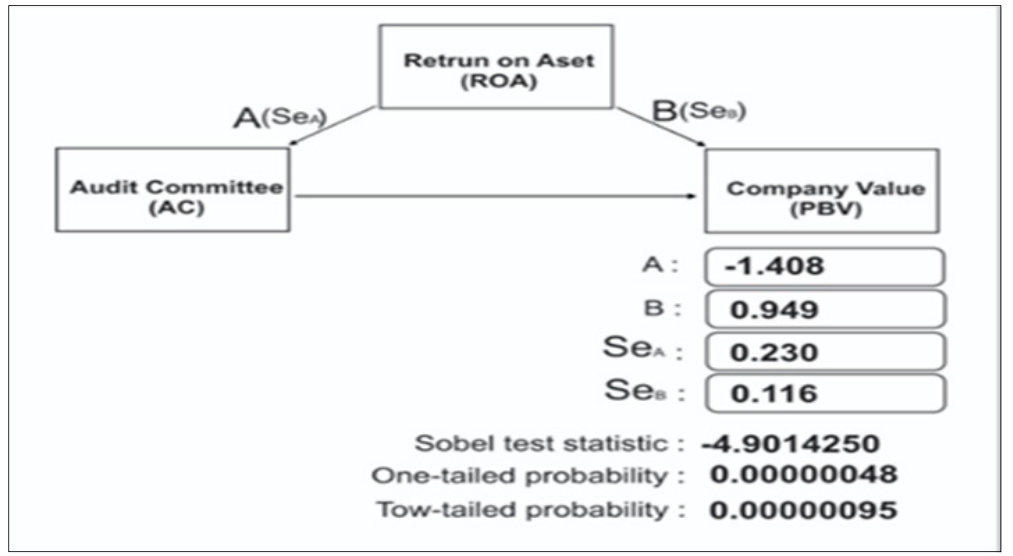

Figure 4.1: Result of the Sobel Test

\section{Conclusion}

The findings of hypothesis analysis show that there is a significant impact of VAIC and the Audit Committee on ROA partially. This describes the effect of VAIC and Audit Committee on the increase in ROA. It was also found that independent commissioners have no significant impact related to ROA partially, which means that the large number of independent commissioners did not affect the increase in ROA. Meanwhile, there is a significant and positive effect of VAIC and the audit committee on Company Value partially. This implies that the VAIC and audit committee affects the increase in firm value.

It is recommended for future studies to use other variables from mechanisms of corporate governance such as commissioners' board. Each banking company must focus on implementation of intellectual capital to generate corporate profits that can enhance financial performance and company value. At first, the investors have to look at annual financial statements if they want to invest in stocks. If the company wants to get a positive VAIC value, it can be shown from the scale of company's revenue compared to the small cost. Whereas audit committees can be seen in the structure of company membership, and the growing number of audit committees can accelerate ROA and PBV.

\section{References}

Arini, Yenita \& Musdholifah. (2018). The Influence of Intellectual Capital and Good Corporate Governance on Company Value through Financial Performance (Study of Banking Subsector Companies Listed on the Indonesia Stock Exchange for the 2013-2016 Period). Journal of Management Science Surabaya State University, Vol. 6(3), pp. 227-240.

Buallay, Amina, Allam Hamdan, Qasim Zureigat. (2017). Corporate Governance and Firm Performance : Evidence from Saudi Arabia. Australasian Accounting, Business and Finance Journal, Vol. 11(1), pp.78-98.

Daud, R. M., \& Amri, A. (2008). The Influence of Intellectual Capital and Corporate Social Responsibility on Company Performance (Empirical Study on Manufacturing Companies on the Indonesia Stock Exchange). Journal of Accounting Research and Research, Vol. 1(2), pp. 231-231.

Ferial, F., Suhadak, \& Handayani, S. R. (2014). The Effect of Good Corporate Governance on Financial Performance and Its Effect on Company Value (Study of State Owned Enterprises Listed on the Indonesia Stock Exchange for the 2012-2014 Period). Journal of Business Administration, Vol. 33(1), pp. 146-153.

Hadiwijaya, R. C., \& Rohman, A. (2013). The Effect of Intellectual Capital on Firm Value with Financial Performance as an Intervening Variable. Diponegoro Journal of Accounting, Vol. 2(3), pp. 1-7. 
Haryani, Jumratul \& I Newa Nyoman Wiratmaja. (2014). Effect of Company Size, Audit Committee, Implementation of International Financial Reporting Standards and Public Ownership on Audit Delay. EAccounting Journal of Udayana University, Vol. 6(1), pp. 63-78.

Imron, Galih Syaiful. (2013). The Influence of Financial Performance and Firm Size on Firm Value with Corporate Social Responsibility and Good Corporate Governance as Moderation Variables. Potensio, Vol. 18(2).

Junaedi. (2017). Effect of Intellectual Capital on Company Performance, Company Growth and Market Performance (Empirical Study on High Tech and Low Tech Industries). Journal of Informa Indonusa Polytechnic,Vol. 3(1), pp. 63-70.

Kartikasari, Yohannita Dwi. (2017). The Effect of Good Corporate Governance and Intellectual Model on Financial Performance in Financial Sector Companies Listed on the Indonesia Stock Exchange in 2011-2015. Journal of Profita, Vol. 5(8), pp. 1-20.

Khan, Asad, Sarfaraz Tanveer \& Umbreen Maik. (2017). An Empirical Analysis of Corporate Governance and Firm Value : Evidence from KSE-10o Index. Journal of Accounting, Vol.3, pp.119-13o.

Khosa, Amrinder. (2017). Independent Directors and Firm Value of Group-Affiliated Firms. International Journal of Accounting and Information Management, Vol. 25(2), pp. 1-29.

Kuryanto, B., Syafruddin, M. (2008). Effect of Intellectual Capital on Company Performance. National Symposium on Accounting, Vol. 11, pp. 1-30.

Maryanto, H. K. (2017). The Effect of Intellectual Capital and Good Corporate Governance on Company Value with Financial Performance as an Intervening Variable in Manufacturing Companies in the Indonesia Stock Exchange in 2011-2014. Journal of Economics, Vol. 4(1), pp. 1598-1612.

Mukhtaruddin, Relasari, \& Felmania M. (2014). Good Corperatae Governance Mechanism, Corporate Social Responsibility Disclosure On Firm Value: Emperical Study On Listed Company In Indonesia Stock Exchange. International Journal Of Finance and Accounting Studies, Vol.2, pp.2-10.

Nisasmara, Prana Wahyu \& Musdholifah. (2016). Cash Holding, Good Corporate Governance and Firm Value. Journal of Management Dynamics, Vol. 7(2), pp.117-128.

Pratiwi, Tia Rizna. (2017). The Influence of Intellectual Capital and Corporate Governance on Banking Financial Performance in Indonesia. Journal of Accounting and Finance, Vol. 8(1), pp. 85-97.

Rimardhani, H., Hidayat, R. R., \& Dwiatmanto. (2016). The Effect of Good Corporate Governance Mechanisms on Company Profitability (Study of BUMN Companies Registered on the Indonesia Stock Exchange in 20122014). Journal of Business Administration, Vol. 31(1), pp. 167-175.

Ulum, I. (2008). Intellectual Capital and Corporate Financial Performance: An Analysis with the Partial Least Squares Approach. Journal of Accounting and Finance, Vol. 10(2), pp. 77-84.

Ulum, I. (2009). Intellectual Capital. Yogyakarta: Graha Ilmu.

Yuniasih, N. W., Wiramam, D. G,. \& Badera, I. D. N. (2010). Exploration of Company Market Performance: Study Based on Intellectual Capital (Empirical Study of Financial Companies Listed on the Indonesia Stock Exchange). National Symposium on Accounting, Vo.13(19), pp. 1-29.

Yuniasih, Ni Wayan \& Wirakusuma, Made Gede. (2008). The Influence of Financial Performance on Company Value with Disclosure of Corporate Social Responsibility and Good Corporate Governance as Moderating Variables. Journal of Finance.

Yuskar, M., \& Novita, D. (2014). Analysis of the Effect of Intelletual Capital on Firm Value with Financial Performance as an Intervening Variable in Banking Companies in Indonesia. Journal of Management and Business, Vol. 12(4), pp. 331-356. 